\title{
Aerosol optical properties and radiative effect determined from sky-radiometer over Loess Plateau of Northwest China
}

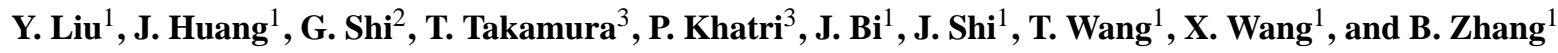 \\ ${ }^{1}$ Key Laboratory for Semi-Arid Climate Change of the Ministry of Education and College of Atmospheric Sciences, Lanzhou \\ University, Lanzhou, 730000, China \\ ${ }^{2}$ LASG, Institute of Atmospheric Physics, Chinese Academy of Sciences, Beijing 100029, China \\ ${ }^{3}$ Center for Environmental Remote Sensing, Chiba University, Chiba, Japan
}

Received: 18 July 2011 - Published in Atmos. Chem. Phys. Discuss.: 24 August 2011

Revised: 8 November 2011 - Accepted: 11 November 2011 - Published: 17 November 2011

\begin{abstract}
The aerosol optical properties and their associated radiative effects are derived from sky-radiometer and surface solar radiation data collected over the Semi-Arid Climate and Environment Observatory of Lanzhou University (SACOL) for the period of March to May (MAM) 2009. The result shows that the seasonal mean aerosol optical depth (AOD) at $500 \mathrm{~nm}$ in MAM is 0.40 . The single scattering albedo (SSA) at $500 \mathrm{~nm}$ in MAM at SACOL fluctuates significantly ranging from 0.82 to 0.98 . The averaged value of SSA there for background aerosol is 0.90 in MAM, while it is smaller (0.87) during the dust event outbreak period. The smaller SSA can be interpreted as the result of larger particles during dust events. The averaged asymmetry factor (ASY) at $500 \mathrm{~nm}$ during dust event period is 0.73 , which is larger than 0.70 of background aerosols. The averaged shortwave radiative effects of the aerosols during dust event period in MAM are $0.68,-70.02$ and $70.70 \mathrm{~W} \mathrm{~m}^{-2}$, respectively, at the top of the atmosphere (TOA), surface and in the atmosphere. The aerosols heat the atmosphere during dust event period by up to about $2 \mathrm{Kday}^{-1}$ (daily averaged), which is $60 \%$ larger than the heating $\left(1.25 \mathrm{~K} \mathrm{day}^{-1}\right)$ of background aerosols. The significant heating effect in the atmosphere of the aerosols during dust event is determined by larger AOD and smaller SSA.
\end{abstract}

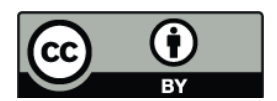

Correspondence to: $\mathrm{Q}$. Fu (qfu@atmos.washington.edu)

\section{Introduction}

Human activities may create a lot of aerosol particles which are important variables in the Earth's energy budget. Aerosols influence the energy balance either by directly absorbing and scattering the shortwave and absorbing and emitting longwave radiation (direct effect) (Charlson et al., 1992; Li and Kou, 1998; Che et al., 2005) or by affecting the size distribution of cloud droplets (indirect effect) $(\mathrm{Li}$, 1998; Ramanathan and Crutzen, 2003). Recently there are many studies on the radiative effect of aerosols, as described in the assessment report of the International Panel on Climate Change (IPCC, 2007), but the quantitative effect of aerosols on energy balance and climate system is still largely uncertain (IPCC, 2007).

Recently, special attention has been dedicated to cloud interactions with desert aerosol particles (Rosenfeld et al., 2001; Bréon et al., 2002; DeMott et al., 2003; Kawamoto and Nakajima, 2003; Huang et al., 2006a, b). However, the knowledge of the effects of Asian dust aerosols on arid climate is still very limited due to the lack of observations. Aerosols are generally believed to exert a cooling influence on the climate directly by scattering solar radiation and through their indirect effects on clouds. However, the semidirect effect has the potential to offset this cooling by reducing low cloud cover and water path. Analysis of the satellite observations indicates that, on average, the water path of dusty clouds is considerably smaller than that from dustfree clouds in the same frontal systems (Huang et al., 2006a, b). The absorption or diabatic heating of Asian dust particles can cause the evaporation of cloud droplets and reduce the

Published by Copernicus Publications on behalf of the European Geosciences Union. 
cloud water path. The key mechanism may be related to the dust aerosol warming effect through the absorption of solar radiation.

To understand the radiative effect of aerosols, it's critical to know the optical and physical properties and their temporal and spatial variability. Many efforts have been devoted to measure aerosol optical and physical properties (Holben et al., 2001; Takemura et al., 2002; Dubovik et al., 2002; Smirnov et al., 2002; Nakajima et al., 2003; Aoki and Fujiyoshi, 2003; Kim et al., 2004; Eck et al., 2005). Uchiyama et al. (2005) studied the characteristics of aeolian dust observed by sky-radiometer at several sites including some in source region. Li et al. (2007) examined continuous highquality measurements of aerosol at Xianghe station in China during the period of September 2004 to September 2005. Retrieving from sky-radiometer measured at Anmyeon, Korea, Sohn et al. (2007) pointed out that Asian dusts can become more absorbing aerosols when mixed with pollutants. Hayasaka et al. (2007) observed the vertical distributions and optical properties of nonspherical dust and spherical aerosol particles from March to May 2005 by Lidar and sky-radiometer systems at Sapporo, Toyama, and Nagasaki, Japan. Xia et al. (2007) studied aerosol optical properties by a Sun photometer at Taihu, China. Che et al. (2008) compared the optical properties derived from Sun photometer and sky-radiometer at Beijing. Huang et al. (2008a) observed the vertical distribution of aerosols in the free troposphere using surface Micro-Pulse Lidar (MPL).

Semi-arid region over Northwest of China has been widely affected by naturally occurring dust storms event especially during the period of early spring to summer. Such event causes not only the serious damage to agriculture, economics, environment and human health in this region but also a climatic impact on the global scale. Ge et al. (2010) retrieved dust aerosol optical properties from Multi-filter Rotating Shadowband Radiometer (MFRSR) and estimated the dust aerosol direct radiative forcing over Northwestern China during the 2008 China-US Joint Field Experiment. Bi et al. (2010) analyzed the aerosol optical properties measured at Semi-Arid Climate and Environment Observatory of Lanzhou University over Loess Plateau of Northwestern China obtained through a CIMEL Sun photometer of the ground-based Aerosol Robotic Network for the period of August 2006-October 2008. However, there are some difference between the results of Ge et al. (2010) and Bi et al. (2010). This study will use another measurement (sky-radiometer) to calculate and check the optical and radiative properties of the dust aerosol at SACOL over Loess Plateau of Northwest China.
Table 1. POM-01 sky-radiometer and CIMEL.

\begin{tabular}{lll}
\hline Instrument & PREDE POM-01 & CIMEL \\
\hline Wavelength & 315, & 440, \\
& 400, & 675, \\
& 500, & 870, \\
& 675, & and $1020 \mathrm{~nm}$ \\
& 870, & \\
& 940, & \\
Field-of-view & and $1020 \mathrm{~nm}$ & $1.0^{\circ}$ \\
\hline Calibration & $1.2^{\circ}$ & Langley method \\
method & Langley and & \\
& improved Langley & \\
\hline
\end{tabular}

\section{Instrument and observational data}

SACOL, located approximately $48 \mathrm{~km}$ from the center of Lanzhou on the southern bank of the Yellow River in Gansu province northwest China $\left(35^{\circ} 57^{\prime} \mathrm{N}, 104^{\circ} 08^{\prime} \mathrm{E}, 1965.8 \mathrm{~m}\right.$ above sea level), is one of the reference sites of the international Coordinated Energy and Water Cycle Observations Project (CEOP). The parent soil material is mainly the Quaternary aeolian Loess with the main soil type of sierozem. The terrain where the measurements were carried out was flat and covered with short grass. Vegetation was usually less than $15 \mathrm{~cm}$ tall and covered less than $80 \%$ of the surface in summer and autumn. SACOL is located within temperate continental climate zone, and the annual mean air temperature is $6.7^{\circ}$. The annual precipitation at SACOL is about $381.8 \mathrm{~mm}$, while the annual mean evaporation is about $1528.5 \mathrm{~mm}$ (Huang et al., 2008b).

POM-01 sky-radiometer has been installed on 15 March 2009 at SACOL to measure the optical properties of aerosols in this region. It has been continuously running since then in 2009. A set of Kipp \& Zonen CM21 pyranometer was also installed to measure the global solar irradiance every 10s automatically at SACOL in March 2009, which is a high precision pyranometer with strictly selected domes. An automatic sun and sky scanning radiometer (CIMEL Sun photometer) was run at SACOL from August 2006, which will be useful to perform inter-comparison of aerosol optical parameters obtained from the two different instruments. The characteristics of the POM-01 sky-radiometer and CIMEL are shown in Table 1. On the calibration of these two instruments, skyradiometer can be calibrated by using not only traditional Langley method but also Improved Langley method.

The sky-radiometer at SACOL was calibrated for the sky radiance using an integrating sphere at Tsukuba Space Center and for the direct solar irradiance using the Improved Langley plot method (Campanelli, 2004). The precision of the in situ method has been estimated to be within $1-2.5 \%$, depending on the wavelength. The CIMEL Sun 
photometer measures the direct sun and diffuse sky radiances within the spectral range 340-1020 nm (Holben et al., 1998). The CIMEL Sun photometer located at SACOL is calibrated at the pristine Mauna Loa Observatory (MLO; latitude: $19^{\circ} 53^{\prime} \mathrm{N}$, longitude: $155^{\circ} 57^{\prime} \mathrm{W}$, elevation: $3400 \mathrm{~m}$ ) once per year.

In view of the advantage on the calibration of skyradiometer, this study will analyze the optical properties observed by sky-radiometer and calculate the radiative effect of the dust aerosols. But comparison of the aerosol optical properties from the sky-radiometer and those from CIMEL will first be performed.

In this study, the latest version of Skyrad package (Version 4.2), which is developed by Nakajima et al. (1996), was used to analyze the data measured by sky-radiometer. During the analysis of sky-radiometer, we need the total amount of ozone and the surface pressure to consider the ozone absorption and the Rayleigh scattering of the air molecules. According to TOMS data and the meteorological observation data at SACOL, we set ozone as $0.3 \mathrm{~cm}$ and surface pressure as 0.78 atm in this study. The pyranometer data was used to remove cloudy data observed by sky-radiometer (Pradeep and Takamura, 2009).

The comparison between the aerosol optical depths observed by CIMEL Sun photometer and POM-01 skyradiometer is first carried out, which is based on the 703 clear-sky measurements from 27 days in March-April-May (MAM). The detailed information of observational days is shown in Table 2. The data can represent the daily and monthly situation according to the measurement days in Table 2. Figure 1 shows the plots of AOD values derived from POM-01 and CIMEL at the two common wavelengths of 675 and $870 \mathrm{~nm}$. Since there is no $500 \mathrm{~nm}$ channel for this CIMEL in the study, we compared the AOD values derived from POM-01 sky-radiometer and CIMEL at the two common wavelengths of 675 and $870 \mathrm{~nm}$. High correlation coefficient of about 0.99 between the AOD from the POM-01 and CIMEL confirms the high consistency of the two instruments. The relative difference in the AOD between the POM-01 and CIMEL is about $3 \%$. Note that the observations shown in Fig. 1 exclude cloudy-sky measurements and the following analysis will only consider the clear-sky observation.

\section{Aerosol optical properties over Loess plateau}

\subsection{Optical depth}

The daily mean AODs at $500 \mathrm{~nm}$ in March, April and May are shown in Fig. 2a, b, and c, respectively. In March the averaged AOD is the largest (0.90) on 21 March and smallest (0.27) on 23 March 2009 (Fig. 2a). In April (Fig. 2b), the averaged AOD is the largest (0.59) on 8 April and smallest
Table 2. The number of clear-sky days and measurements by skyradiometer in spring of 2009 and the retrieved averaged AOD and adjusted SSA and ASY in MAM (unadjusted values are shown in brackets).

\begin{tabular}{lllll}
\hline Month & Mar. & Apr. & May & MAM \\
\hline Days & 11 & 9 & 7 & 27 \\
Measurements & 239 & 261 & 203 & 703 \\
AOD $(500 \mathrm{~nm})$ & 0.50 & 0.42 & 0.28 & 0.40 \\
SSA $(500 \mathrm{~nm})$ & $0.87(0.89)$ & $0.90(0.92)$ & $0.91(0.99)$ & $0.89(0.93)$ \\
ASY $(500 \mathrm{~nm})$ & $0.73(0.72)$ & $0.72(0.71)$ & $0.69(0.68)$ & $0.71(0.70)$ \\
\hline
\end{tabular}
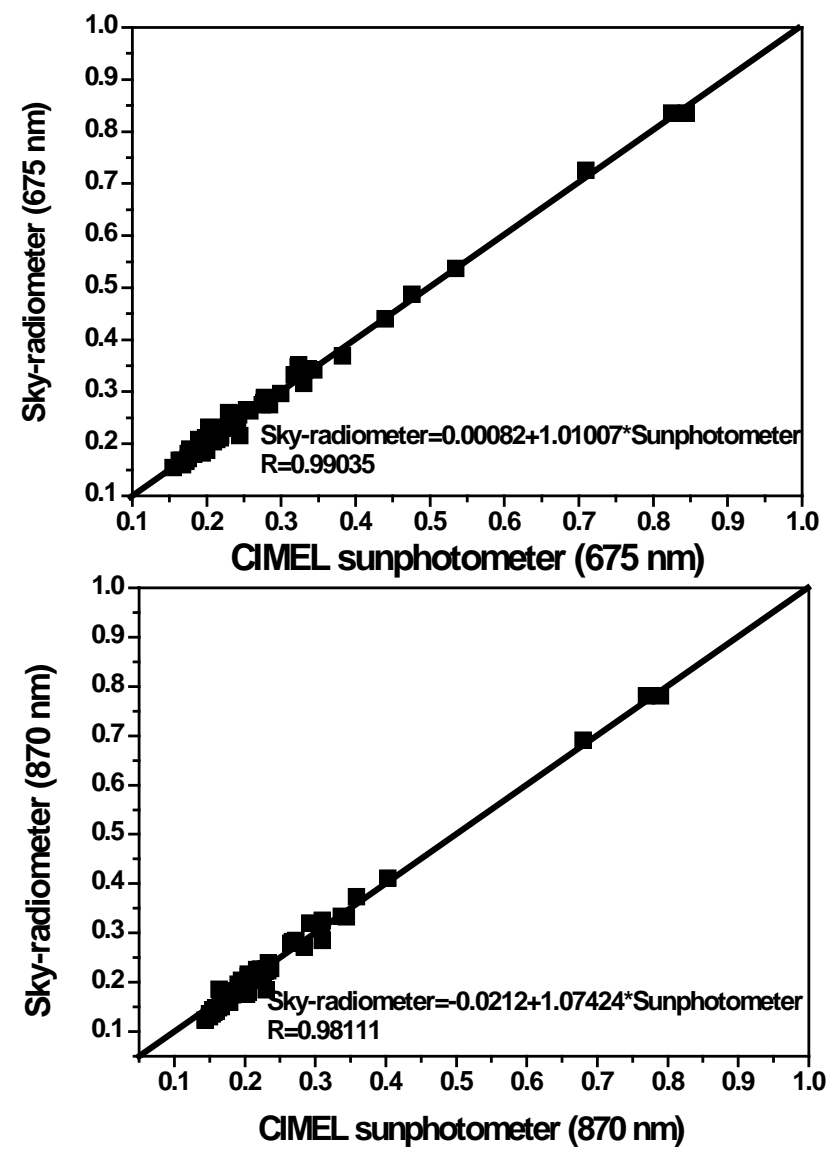

Fig. 1. AOD measured by POM-01 versus CIMEL in MAM at SACOL.

(0.26) is on 7 April 2009. The AOD is the largest (0.69) on 10 May and smallest (0.21) on 22 May (Fig. 2c).

Checking the observed solar irradiance, meteorological report at SACOL, and retrieved AOD and Angstrom wavelength exponent, we found that 19, 21, 23, 25, 29, 31 March and 8 April 2009 are dusty days among the measurements in this study. During these days, almost all the Angstrom exponents are less than 0.5. The daily mean values of Angstrom exponent on 19, 21, 23, 25, 29, and 31 March, and 8 April are $0.47,0.10,0.32,0.25,0.40,0.27$, and 0.56 , respectively. 

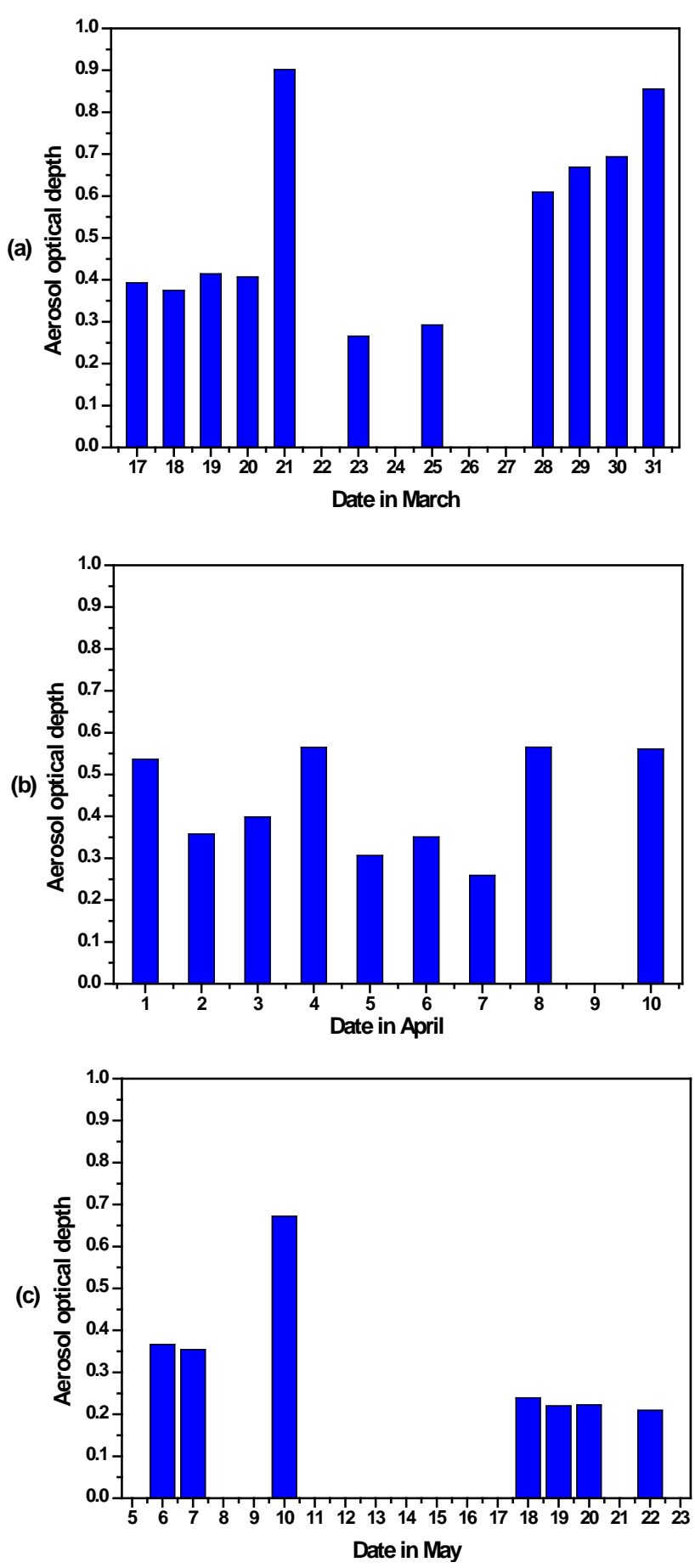

Fig. 2. Daily averaged AOD at $500 \mathrm{~nm}$ in March (a), April (b) and May (c).

In fact, according to the weather record, there are even more heavy dust events which were not caught by POM-01 but occurred on 23 April 2009, for example. As described by Uchiyama et al. (2005), if it is cloudy or very heavy dust storm, we cannot make the measurements. Thus the sky-

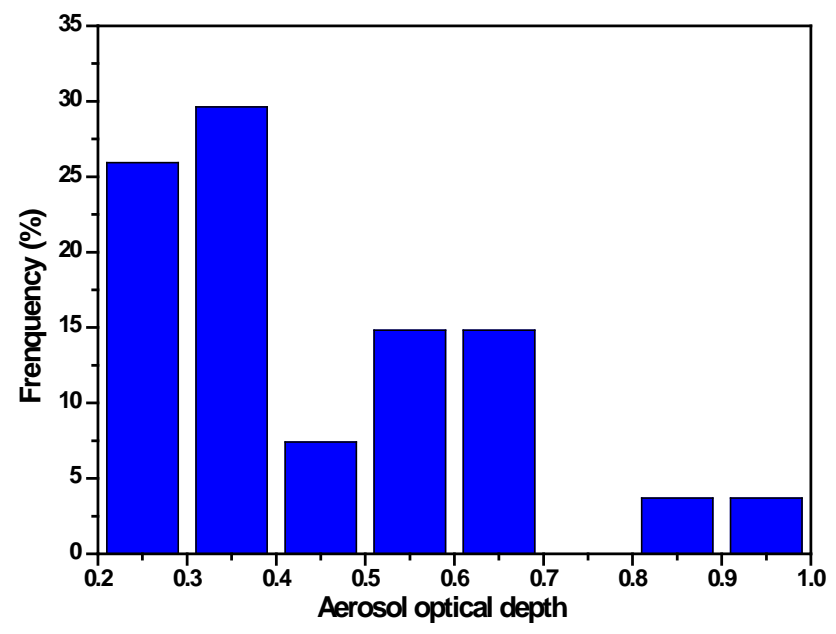

Fig. 3. AOD frequency distributions at $500 \mathrm{~nm}$ in MAM 2009 at SACOL.

radiometer might miss some very heavy dust events during the observational period in spring at SACOL. In the following, through the weather record and aerosol optical analysis from CIMEL and sky-radiometer observation, we define the observational days without obvious dust events as the clean day as background atmosphere.

Table 2 shows that the overall (including background and dusty days) monthly averaged AODs at $500 \mathrm{~nm}$ are $0.50,0.42$ and 0.28 in March, April and May, respectively. One can find that the monthly mean AOD is the largest in March and smallest in May, which agrees with the high frequency of dust event in March over Loess Plateau. The overall seasonal averaged AOD at $500 \mathrm{~nm}$ for spring is 0.40 , which is comparable to the result derived from CIMEL $(0.415 \pm 0.23)$ at SACOL (Bi et al., 2010).

For the background aerosols at SACOL, the monthly averaged AODs are significant different (shown in Table 3). The averaged AOD of background aerosols (0.42) at $500 \mathrm{~nm}$ in MAM is much smaller than that during dust event (0.57).

Figure 3 gives the frequency distributions of AOD at $500 \mathrm{~nm}$ observed by sky-radiometer in MAM at SACOL. As also shown in Fig. 2, the AOD at $500 \mathrm{~nm}$ in MAM fluctuates with range from 0.2 to 1.0 during the measurement days. We find that most of the AOD values (about $60 \%$ ) are in the range from 0.2 to 0.4 , in which the highest frequency of the AOD values (about $30 \%$ ) is in the range from 0.3 to 0.4 .

\subsection{Single scattering albedo and asymmetry factor}

During the observation days measured by POM-01, the daily mean SSAs at $500 \mathrm{~nm}$ derived from sky-radiometer range from 0.8 to $0.95,0.83$ to 0.95 and 0.98 to 0.99 in March, April and May, respectively. The monthly mean SSA retrieved directly is the largest (0.99) for May and smallest 

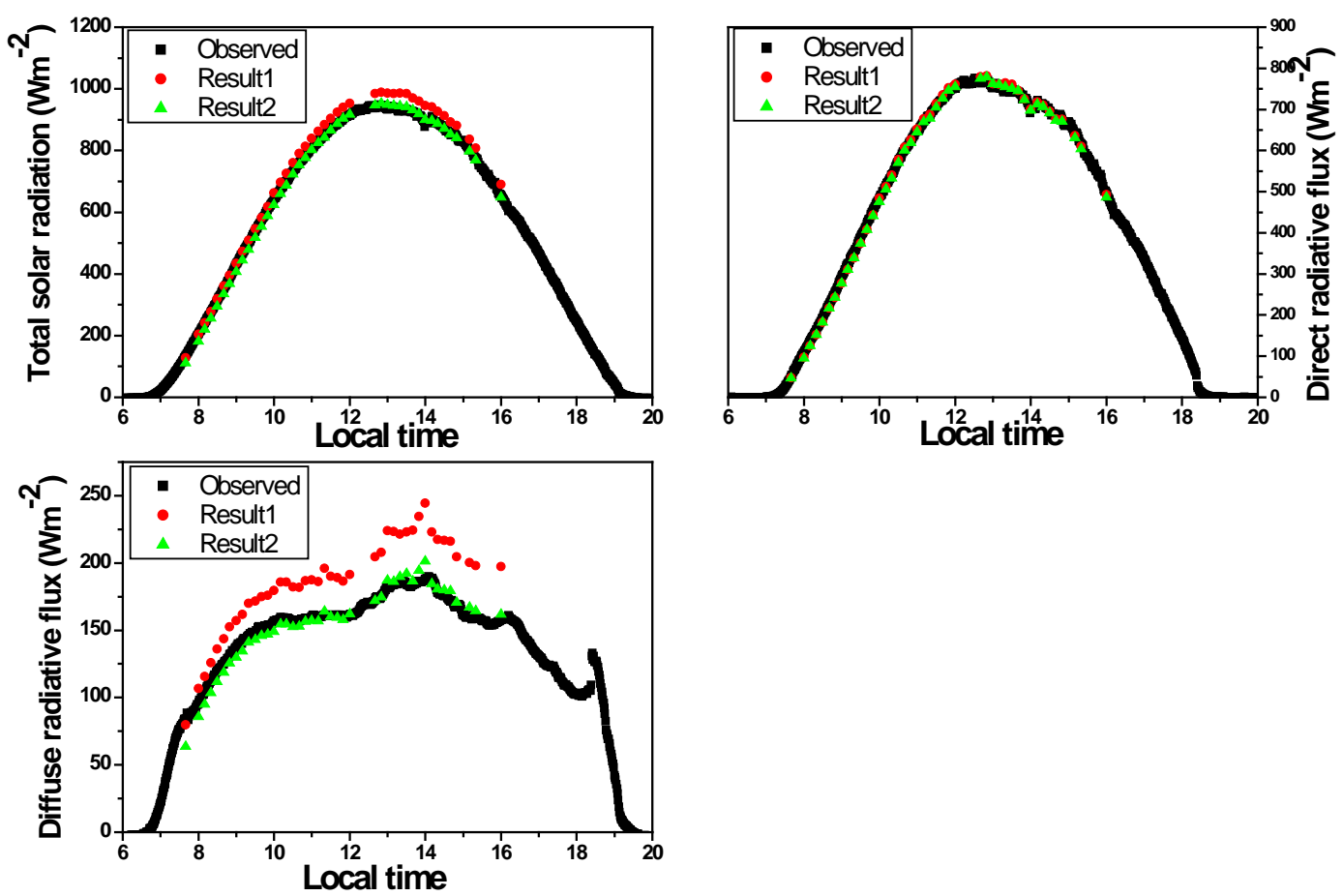

Fig. 4. Difference among observed and calculated broadband (a) total, (b) direct and (c) diffuse radiative flux at the surface on a clean sky (7 April 2009).

Table 3. Averaged AOD, SSA, ASY and ARF of background and dusty days in MAM (AOD is retrieved from sky-radiometer directly; SSA and ASY are adjusted values; ARF is calculated by radiative transfer model with retrieved AOD and adjusted SSA and ASY).

\begin{tabular}{lrrrrrr}
\hline & \multicolumn{4}{c}{ Background } & & Dusty day \\
\cline { 2 - 4 } & March & April & May & MAM & & MAM \\
\hline Days & 5 & 8 & 7 & 20 & 7 \\
AOD (500 nm) & 0.50 & 0.42 & 0.33 & 0.42 & & 0.57 \\
SSA (500 nm) & 0.88 & 0.89 & 0.92 & 0.90 & & 0.87 \\
ASY (500 nm) & 0.70 & 0.72 & 0.68 & 0.7 & \\
ARFsrf & -63.19 & -55.77 & -38.45 & -52.47 & & -70.02 \\
ARFtoa & -13.35 & -8.83 & -7.78 & -10.00 & & 0.68 \\
ARFatm & 49.83 & 46.95 & 30.68 & 42.49 & & 70.70 \\
\hline
\end{tabular}

(0.89) in March at SACOL and the monthly mean ASY at SACOL ranges from 0.68 to 0.72 in MAM

We will further examine the SSA and ASY using the radiative closure experiments in Sect. 4.1 where we found that there may be smaller than these retrieved values.

\section{Radiative effect of dust aerosol}

\subsection{Comparison between the observed and simulated radiative fluxes}

Before calculating the aerosol radiative forcing (ARF), we must determine the accuracy of the retrieved aerosol optical properties from POM-01 sky-radiometer. Using SBDART model (Ricchiazzi et al., 1998), we simulated the solar radiation fluxes (total, direct and diffuse) at the surface using the retrieved aerosol optical properties including AOD, SSA and ASY. According to the average humidity profile derived from microwave radiometer at SACOL, we chose atmospheric profile as sub-arctic winter atmosphere (water vapor is $0.418 \mathrm{~g} \mathrm{~cm}^{-2}$ ) in simulation. The spectral variation of aerosol optical properties is set ranging from 0.305 to 2.8. The values of precipitable water content (PWC) are taken from the observation of microwave radiometer (MWR) at SACOL. Additionally, we considered that the effect of surface albedo error on the aerosol optical property is small and the surface albedo is set as 0.2 for all wavelengths in this study.

To consider the uncertainty of the observation by CM21, we investigated the temperature dependence of the response of CM21 to radiation by examining the data for the 30-min periods before sunrise and after sunset. The output of CM21 showed the maximum negative value about $-2.0 \mathrm{~W} \mathrm{~m}^{-2}$. After considering the uncertainty of CM21, we regard the 

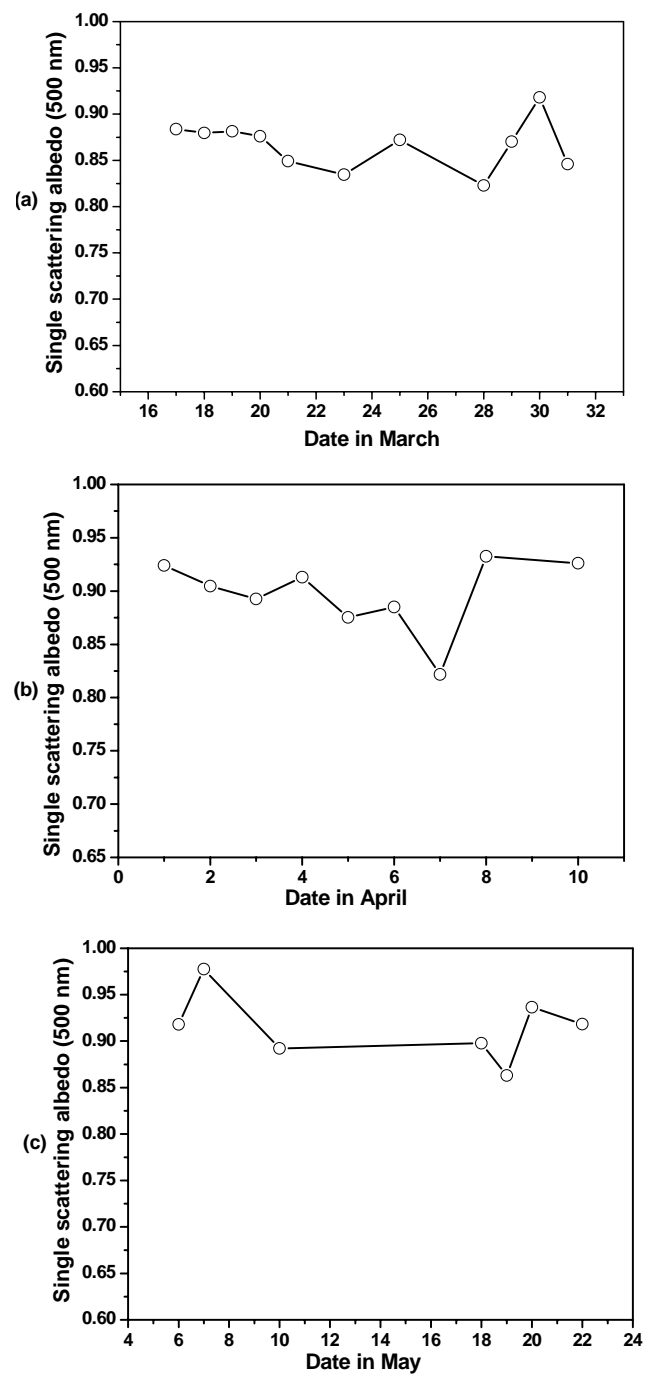

Fig. 5. Daily averaged SSA (after being adjusted) at $500 \mathrm{~nm}$ in March (a), April (b) and May (c).

radiative flux observed by $\mathrm{CM} 21$ as a reference. Comparing the calculated broadband radiative fluxes with these observed by pyranometer and pyrheliometer during the same days at SACOL, the relative differences in the direct, total and diffuse radiation are $1.2 \%, 3.05 \%$ and $12.56 \%$, respectively. The good agreement between the calculated and observed direct radiations indicates that the retrieved AOD are accurate, which was also shown in the comparison with the AOD by CIMEL (Fig. 1). The disagreement between the diffuse fluxes indicates that the SSA derived from sky-radiometer may have significant errors. To obtain the accurate ARF, we must adjust SSA and ASY to make the calculated radiative fluxes agree the observed ones. Basing on the solar irradiance observed by CM21 (measurement error is considered), if the simulated values of diffuse irradiance were larger than observed ones, we decrease SSAs and increase

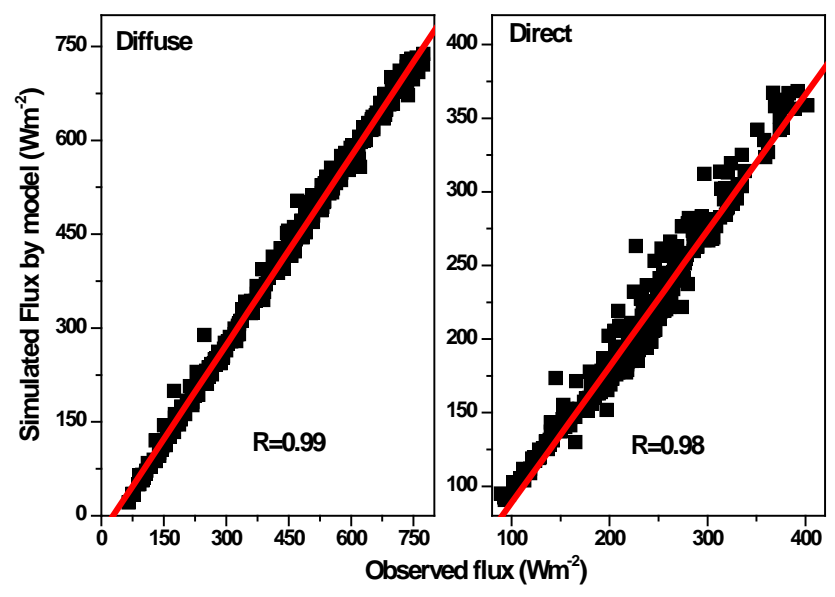

Fig. 6. Scattergrams of the observed and calculated solar irradiance at the surface after adjusting SSA and ASY.

ASYs simultaneously until the relative difference between observed and calculated diffuse flux could be less than about $3 \%$. Of course, for the days in which the difference between observed and simulated diffuse fluxes is less than about $3 \%$, we considered the SSAs and ASYs are reliable calculated the ARF directly.

Figure 4 shows an example of radiative closure experiment. In Fig. 4, result 1 is the calculated result using the retrieved aerosol optical properties directly including AOD, SSA and ASY; result 2 is the simulation after adjusting the SSA at $500 \mathrm{~nm}$ from 0.92 to 0.82 . We found that the values of SSA observed by POM-01 are larger than the real values at SACOL, i.e., the SSA retrieved from sky-radiometer maybe underestimate the absorption of the aerosols over the Loess Plateau in Northwest of the China.

The daily mean values of adjusted SSA at $500 \mathrm{~nm}$ are shown in Fig. 5 ranging from 0.82 to 0.98 at $500 \mathrm{~nm}$ in MAM at SACOL. The adjusted mean SSA at $500 \mathrm{~nm}$ is 0.89 in MAM, while the unadjusted (shown in bracket in Table 2) mean SSA is 0.93 . The relative difference in the mean SSA between adjusted and unadjusted value is about $4 \%$ in MAM. Compared with the SSA observed at the other observatory over the Loess Plateau (Ge et al., 2010), the values of the SSA (adjusted) are larger in this study. The adjusted ASY at $500 \mathrm{~nm}$ ranges from 0.65 to 0.74 in MAM (not shown in figure).

As shown in Table 3, the background monthly mean SSA is the larger (0.92) in May and April and smaller (0.88) in March at SACOL. The averaged SSA of background is 0.90 in MAM at SACOL, while the mean value during dust events is 0.87 which is slightly lower than the 0.89 of Dunhuang (Kim et al., 2004). The smaller SSA can be manily interpreted as the result of larger particles during dust events (Fu et al., 2009). The averaged ASY during dust period is much larger than that of background aerosols, which is reflected by large coarse and large fine mode volume in size distribution 
during dust day and background aerosols, respectively. Large ASY during dust events indicates that the lager dust particles lead to stronger forward scattering (Fu et al., 2009). Figure 6 shows the comparison of the observed solar irradiances (direct and diffuse) and those calculated by radiative transfer model using adjusted SSAs and ASYs, indicating a good agreement.

Based on the calculated solar radiation at the TOA and surface by using the adjusted SSAs and ASYs, we calculate the aerosol shortwave radiative heating rate at SACOL (not shown). The aerosols during dust event period have a larger impact on the radiative energy budget than background aerosols over Loess Plateau. The maximum 24-h averaged radiative heating rate reaches $2 \mathrm{Kday}^{-1}$ on 21 March which was a strong dusty day. The aerosols heat the atmosphere (daily averaged) by up to about $2 \mathrm{~K} \mathrm{day}^{-1}$ due to dust event, which is $60 \%$ larger than the heating $\left(1.25 \mathrm{~K} \mathrm{day}^{-1}\right)$ of background aerosols.

\subsection{Radiative forcing due to dust aerosol}

The ARF at the surface is estimated as follows,

$\mathrm{ARF}_{\mathrm{SRF}}=\bar{F}_{\text {are }}(1-R)$

where $R$ is the surface reflectance, and

$\bar{F}_{\text {are }}=\frac{\int\left[F_{\text {obs }}(t)-F_{\mathrm{SRF}, \text { Ray }}(t)\right] d t}{24 \cdot 3600}$

$F_{\text {obs }}(t)$ is the observed solar irradiance at the surface (SRF) and time $t . F_{\mathrm{SRF}, \mathrm{Ray}}(t)$ is the downward solar irradiance at the surface and time $t$ for aerosol-free atmosphere, which is estimated by a radiative transfer calculation using the SBDART model. The integration term in Eq. (2) shows the radiative effect of aerosol. Using Eqs. (1) and (2), we can calculated the ARF (ARF $\mathrm{SRF}_{\mathrm{SR}}^{\mathrm{CM}}$ ) based on the global solar irradiance observed by $\mathrm{CM} 21$ at $\mathrm{SACOL}$ and regard $\mathrm{ARF}_{\mathrm{SRF}}^{\mathrm{CM} 1}$ as a reference to the simulated ARF by SBDART after considering the uncertainty of CM21.

Using the SBDART model, ARF at the surface $\left(\mathrm{ARF}_{\mathrm{SRF}}^{\mathrm{SBDART}}\right)$ can be calculated as follows,

$\mathrm{ARF}_{\mathrm{SRF}}^{\mathrm{SBDART}}=\overline{F_{\mathrm{SRF}}^{N}}-\overline{F_{\mathrm{SRF}, \mathrm{Ray}}^{N}}$

where $\overline{F_{\mathrm{SRF}}^{N}}$ and $\overline{F_{\mathrm{SRF}, \text { Ray }}^{N}}$ are the daily mean net solar radiation at the surface with and without aerosols, respectively.

Figure 7 shows the comparison of the ARF calculated by the radiative transfer model and that derived from the CM21 observation. $\mathrm{ARF}_{\mathrm{SRF}}^{\mathrm{CM} 21}$ and $\mathrm{ARF}_{\mathrm{SRF}}^{\mathrm{SBDART}}$ shows a high correlation with a mean bias of about $4.69 \mathrm{~W} \mathrm{~m}^{-2}$

ARF at the top of atmosphere and in the atmosphere (ATM) could be calculated using the radiative transfer model as follows

$\mathrm{ARF}_{\mathrm{TOA}}={\overline{F_{\mathrm{TOA}}}}^{N}-\overline{\bar{F}_{\mathrm{TOA}, \mathrm{Ray}}^{N}}$

$\mathrm{ARF}_{\mathrm{ATM}}=\mathrm{ARF}_{\mathrm{TOA}}-\mathrm{ARF}_{\mathrm{SRF}}$

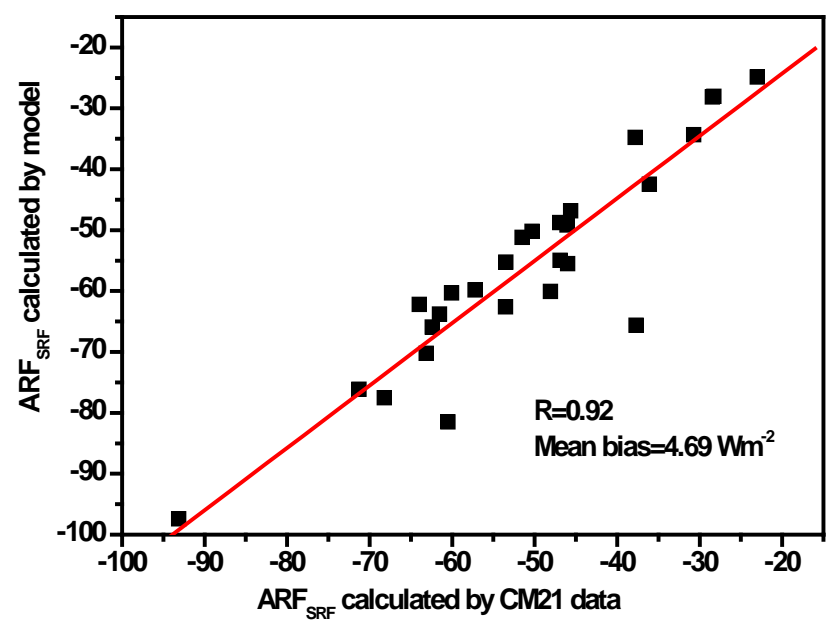

Fig. 7. Scattergrams of daily mean ARF calculated by CM21 observation and the radiative transfer model.

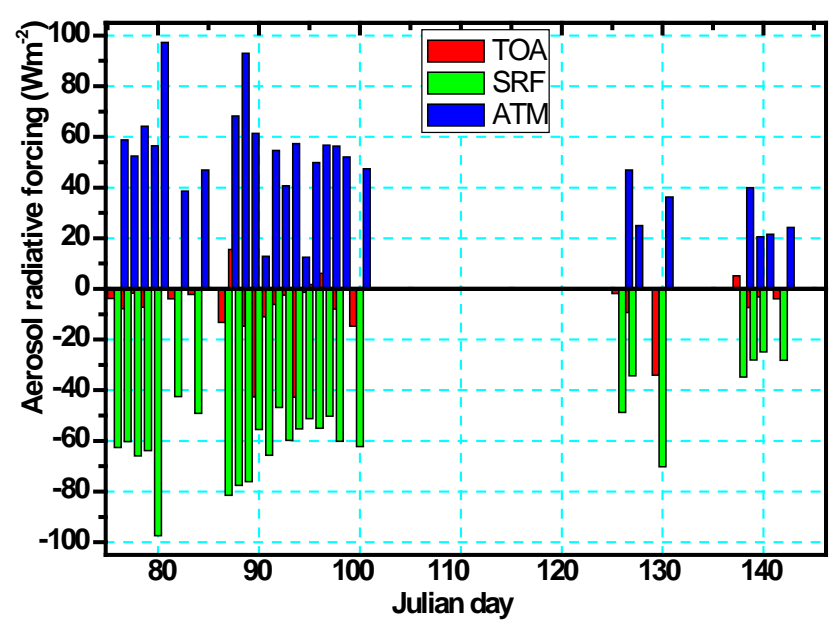

Fig. 8. Daily mean ARF at the surface (green), top of the atmosphere (red) and in the atmosphere (blue) in MAM 2009 at SACOL.

where $\overline{F_{\mathrm{TOA}}^{N}}$ and $\overline{F_{\mathrm{TOA}, \text { Ray }}^{N}}$ are daily mean net solar radiative flux at the TOA with and without aerosols, respectively. Figure 8 shows the daily mean radiative forcing at the surface (green), TOA (red) and in the atmosphere (blue) in MAM 2009.

Aerosols at SACOL have a strong negative radiative forcing at the surface, ranging from -24.85 to $-97.41 \mathrm{~W} \mathrm{~m}^{-2}$. The negative forcing is the largest $\left(-97.41 \mathrm{~W} \mathrm{~m}^{-2}\right)$ on 21 March 2009, which corresponds with the largest value of AOD in MAM 2009. The surface ARF at other site over loess plateau of Northwest China (Ge et al., 2010) ranges from -7.9 to $-35.8 \mathrm{~W} \mathrm{~m}^{-2}$ from 25 April to 25 May, while the averaged $\mathrm{ARF}$ at the surface in our study ranges from -24.85 to $-70.26 \mathrm{~W} \mathrm{~m}^{-2}$ from April to May. The critical reason of such difference is the larger optical depth in our study. Daily averaged values of radiative forcing at the surface in May are 
smaller than that in March and April. Most of the ARF values at the TOA are negative, and the value of ARF fluctuates from 15.51 to $-42.8 \mathrm{~W} \mathrm{~m}^{-2}$. In general, the ARF in the atmosphere, which represents absorbed solar radiation within the atmosphere, heats the atmosphere (Miller et al., 1998, 1999). In this study, aerosols have a heating effect in the atmosphere especially during the dust event period, which range from 12.49 to $97.24 \mathrm{~W} \mathrm{~m}^{-2}$.

We also calculated the daily-average surface aerosol radiative forcing efficiency (ARFE), which is defined as the diurnally-averaged ARF divided by the daily-average AOD. For easy comparison to other work, we used the AOD at $500 \mathrm{~nm}$ to calculate the ARFE. The average surface ARFE is $-132.24 \mathrm{~W} \mathrm{~m}^{-2} \tau^{-1}(\tau$ is the AOD at $500 \mathrm{~nm})$. The result of Kim et al. (2005) shows that the values of ARFE due to Asian dust can range from -55 to $-106 \mathrm{~W} \mathrm{~m}^{-2} \tau^{-1}$, our result is about $25 \mathrm{~W} \mathrm{~m}^{-2} \tau^{-1}$ larger than the value at the larger (in absolute value) end of this range.

As shown in Table 3, the heating effect in the atmosphere (positive ARF, $70.70 \mathrm{~W} \mathrm{~m}^{-2}$ ) of the aerosols during dust event period is much more significant than background aerosol (ARF in the atmosphere is $42.49 \mathrm{~W} \mathrm{~m}^{-2}$ ) in MAM 2009, which is determined by the larger optical depth and smaller SSA of the dust aerosols during dust event over Loess Plateau in Northwest of the China.

\section{Conclusions and summary}

In this study, we investigated the aerosol optical properties and their associated radiative forcing retrieved from the POM-01 sky-radiometer and surface solar radiation data collected at the Semi-Arid Climate and Environment Observatory of Lanzhou University (SACOL) in MAM 2009. The aerosol radiative forcing was simulated by SBDART model. The aerosol optical property was retrieved from the skyradiometer. SSA was obtained by matching the simulation using radiative transfer model with observation. The averaged SSA of background aerosols is 0.90 in MAM, while the mean value due to dust events is 0.87 .

The maximum 24-h averaged radiative heating rate reaches about $2 \mathrm{Kday}^{-1}$ on 21 March which was a strong dusty day. The aerosols heat the atmosphere (daily averaged) by up to $2 \mathrm{~K} \mathrm{day}^{-1}$ due to dust event, which is $60 \%$ larger than the heating $\left(1.25 \mathrm{~K} \mathrm{day}^{-1}\right)$ of background aerosols.

The heating effect in the atmosphere (positive ARF, $70.70 \mathrm{~W} \mathrm{~m}^{-2}$ ) of the aerosols during dust event period is much more significant than background aerosol (ARF in the atmosphere is $42.49 \mathrm{~W} \mathrm{~m}^{-2}$ ) in MAM 2009. Dust aerosols may heat the atmosphere strongly at SACOL.

Acknowledgements. This work was financially jointly supported by the National Basic Research Program of China (2012CB955302) and Grant National Science Foundation of China under grant 40725015, 40730949.
Edited by: D. Knopf

\section{References}

Aoki, K. and Fujiyoshi, K.: Sky Radiometer Measurements of Aerosol Optical Properties over Sapporo, Japan. J. Meteorol. Soc. Jpn., 81, 493-513, 2003.

Bi, J. R., Huang, J. P., Fu, Q., Shi, J. S., Zhang, W., Wang, X., Huang, Z. W., and Zhang, B. D.: Toward characterization of the aerosol optical properties over Loess Plateau of Northwestern China, 2010, J. Quant. Spectrosc. Radiat. Trans., 112, 346-360, 2011.

Bréon, F. M., Tanre, D., and Generoso, S.: Aerosol effect on cloud droplet size monitored from satellite, Science, 295, 834-838, 2002.

Campanelli, M., Nakajima, T., and Olivieri, B.: Determination of the Solar Calibration Constant for a Sun-Sky Radiometer, Proposal of an In-Situ Procedure, Appl. Optics, 43, 651-659, 2004.

Charlson, R. J., Schwartz, S. E., Hales, J. M., Cess, R. D., Coakley, J. A., Hansen Jr., J. E., and Hofmann, D. J.: Climate forcing by anthropogenic aerosols, Science, 255, 423-430, 1992.

Che, H. Z., Shi, G., Uchiyama, A., Yamazaki, A., Chen, H., Goloub, P., and Zhang, X.: Intercomparison between aerosol optical properties by a PREDE skyradiometer and CIMEL sunphotometer over Beijing, China, Atmos. Chem. Phys., 8, 3199-3214, doi:10.5194/acp-8-6365-2008, 2008.

Che, H. Z., Shi, G. Y., Zhang, X. Y., Arimoto, R., Zhao, J. Q., Xu, L., Wang, B., and Chen, Z. H.: Analysis of 40 years of solar radiation data from China, 1961-2000, Geophys. Res. Lett., 32, L06803, doi:10.1029/2004GL022322, 2005.

DeMott, P. J., Sassen, K., Poellot, M., Baumgardner, D., Rogers, D. C., Brooks, S., Prenni, A. J., and Kreidenweis, S. M.: African dust aerosols as atmospheric ice nuclei, Geophys. Res. Lett., 30, 1732, doi:10.1029/2003GL017410, 2003.

Dubovik, O., Holben, B. N., Eck, T. F., Smirnov, A., Kaufman, Y. J., King, M. D., Tanre, D., and Slutsker, I.: Variability of absorption and optical properties of key aerosol types observed in worldwide locations, J. Atmos. Sci., 59, 590-608, 2002.

Eck, T. F., Holben, B. N., Dubovik, O., Smirnov, A., Goloub, P., Chen, H. B., Chatenet, B., Gomes, L., Zhang, X. Y., Tsay, S. C., Ji, Q., Giles, D., and Slutske, I.: Columnar aerosol optical properties at AERONET sites in central eastern Asia and aerosol transport to the tropical mid-Pacific, J. Geophys. Res., 110, D06202, doi:10.1029/2004JD005274, 2005.

Fu, Q., Thorsen, T. J., Su, J., Ge, J. M., and Huang, J. P.: Test of Mie-based single-scattering properties of non-spherical dust aerosols in radiative flux calculations, J. Quan. Spectro. Rad. Trsnsfer, 110, 1640-1653, doi:10.1016/j.jqsrt.2009.03.010, 2009.

Ge, J. M., Su, J., Ackerman, T. P., Fu, Q., Huang, J. P., and Shi, J. S.: Dust Aerosol Optical Properties Retrieval and Radiative Forcing over Northwestern China during the 2008 ChinaUS Joint Field Experiment, J. Geophys. Res., 115, D00K12, doi:10.1029/2009JD013263, 2010.

Hayasaka, T., Satake, S., Shimizu, A., Sugimoto, N., Matsui, I., Aoki, K., and Muraji, Y.: Vertical distribution and optical properties of aerosols observed over Japan during the Atmospheric Brown Clouds-East Asia Regional Experiment 2005, J. Geophys. Res., 112, D22S35, doi:10.1029/2006JD008086, 2007. 
Holben, B. N., Eck, T. F., Slutsker, I., Tanre, D., Buis, J. P., Setzer, A., Vermote, E., Reagan, J. A., Kaufman, Y. J., Nakajima, T., Lavenu, F., Jankowiac, I., and Smirnov, A.: AERONET - A federated instrument network and data archive for aerosol characterization, Remote Sens. Environ., 66, 1-16, 1998.

Holben, B. N., Tanré, D., Smirnov, A., Eck, T. F., Slutsker, I., Abuhassan, N., Newcomb, W. W., Schafer, J. S., Chatenet, B., Lavenu, F., Kaufman, Y. J., Castle, J. V., Setzer, A., Markham, B., Clark, D., Frouin, R., Halthore, R., Karneli, A., O’Neill, N. T., Pietras, C., Pinker, R. T., Voss, K., and Zibordi, G.: An emerging ground-based aerosol climatology: Aerosol optical depth from AERONET, J. Geophys. Res., 106, 12067-12097, 2001.

Huang, J. P., Lin, B., Minnis, P., Wang, T., Wang, X., Hu, Y., Yi, Y., and Ayers, J. K.: Satellite-based assessment of possible dust aerosols semi-direct effect on cloud water path over East Asia, Geophys. Res. Lett., 33, L19802, doi:10.1029/2006GL026561, 2006a.

Huang, J. P., Minnis P., Lin, B., Wang, T., Yi, Y., Hu, Y., SunMack, S., and Ayers, K.: Possible influences of Asian dust aerosols on cloud properties and radiative forcing observed from MODIS and CERES, Geophys. Res. Lett., 33, L06824, doi:10.1029/2005GL024724, 2006b.

Huang, J. P., Huang, Z. W., Bi, J. R., Zhang, W., and Zhang, L.: Micro-pulse lidar measurements of aerosol vertical structure over the Loess Plateau, Atmos. Ocean. Sci. Lett., 1, 8-11, 2008a.

Huang, J. P., Zhang, W., and Zuo, J., Bi, J., Shi, J., Wang, X., Chang, Z., Huang, Z., Yang, S., Zhang, B., Wang, G., Feng, G., Yuan, J., Zhang, L., Zuo, H., Wang, S., Fu, Q., and Chou, J.: An overview of the Semi-Arid Climate and Environment Research Observatory over the Loess Plateau, Adv. Atmos. Sci., 25, 1-16, 2008b.

Intergovernmental Panel on Climate Change (IPCC): Climate Change 2007: in: The Scientific Basis, edited by: Solomon, S., Qin, D., Manning, M., Chen, Z., Marquis, M., Averyt, K. B., Tignor, M., and Miller H. L., Cambridge Univ. Press, New York, USA, 2007.

Kawamoto, K. and Nakajima, T.: Seasonal variation of cloud particle size from AVHRR remote sensing, Geophys, Res. Lett., 30, 1810-1813, 2003.

Kim, D. H., Sohn, B. J., Nakajima, T., Takamura, T., Choi, B. C., and Yoon, S. C.: Aerosol optical properties over east Asia determined from ground-based sky radiation measurements, J. Geophys. Res., 109, D02209, doi:10.1029/2003JD003387, 2004.

$\mathrm{Li}, \mathrm{Z}$.: Influence of absorbing aerosols on the inference of solar surface radiation budget and cloud absorption, J. Climate, 11, 517, 1998.

Li, Z. and Kou, L.: Atmospheric direct radiative forcing by smoke aerosols determined from satellite and surfase measurements, Tellus B, 50, 543-554, 1998.
Li, Z., Xia, X., Cribb, M., Mi, W., Holben, B., Wang, P., Chen, H., Tsay, S. C., Eck, T. F., Zhao, F., Dutton, E. G., and Dickerson, R. R.: Aerosol optical properties and their radiative effects in northern China, J. Geophys. Res., 112, D22S01, doi:10.1029/2006JD007382, 2007.

Nakajima, T., Tonna, G., Rao, R., Kaufman, Y., and Holben, B.: Use of sky-brightness measurements from ground for remote sensing of particulate polydispersions, Appl. Opt., 35, 26722686, 1996.

Nakajima, T., Sekiguchi, M., Takemura, T., Uno, I., Higurashi, A., Kim, D., Sohn, B. J., Oh, S.-N., Nakajima, T. Y., Ohta, S., Okada, I., Takamura, T., and Kawamoto, K.: Significance of direct and indirect radiative forcings of aerosols in the East China Sea region, J. Geophys. Res., 108(D23), 8658, doi:10.1029/2002JD003261, 2003.

Pradeep, K. and Takamura, T.: An algorithm to screen cloudaffected data for sky radiometer data analysis, J. Meteor. Soc. Jpn., 87, 189-204, 2009.

Ramanathan, V. and Crutzen, P. J.: New directions: Atmospheric brown 'clouds', Atmos. Environ., 37, 4033-4035, 2003.

Ricchiazzi, P., Yang, S., Gautier, C., and Sowle, D.: SBDART: A research and teaching software tool for plane-parallel radiative transfer in the Earth's atmosphere, Bull. Amer. Meteor. Soc., 79, 2101-2114, 1998.

Rosenfeld, D., Rudich, Y., and Lahav, R.: Desert dust suppressing precipitation: A possible desertification feedback loop, Proc. Natl. Acad. Sci., 98, 5975-5980, 2001.

Smirnov, A., Holben, B. N., Eck, T. F., Slutsker, I., Chatenet, B., and Pinker, R. T.: Diurnal variability of aerosol optical depth observed at AERONET (Aerosol Robotic Network) sites, Geophys. Res. Lett., 29, 2115, doi:10.1029/2002GL016305, 2002.

Sohn, B. J., Nakajima, T., Chun, H. W., and Aoki, K.: More Absorbing Dust Aerosol Inferred from Sky Radiometer Measurements at Anmyeon, Korea, J. Meteorol. Soc. Jpn., 85, 815-823, 2007.

Takemura, T., Nakajima, T., Dubovik, O., Holben, B. N., and Kinne, S.: Single scattering albedo and radiative forcing of various aerosol species with a global three-dimensional model, J. Climate, 15, 333-352, 2002.

Uchiyama, A., Yamazaki, A., Togawa, H., and Asano, J.: Characteristics of Aeolian dust observed by sky radiometer in the ADEC Intensive Observation Period I (IOP1), J. Meteorol. Soc. Jpn., 83A, 291-305, 2005.

Xia, X., Li, Z., Holben, B., Wang, P., Eck, T., Chen, H., Cribb, M., and Zhao, Y.: Aerosol optical properties and radiative effects in the Yangtze Delta region of China, J. Geophys. Res., 112, D22S12, doi:10.1029/2007JD008859, 2007. 